\title{
PEMISKINAN TERHADAP PELAKU TINDAK PIDANA KORUPSI DALAM PERSPEKTIF HUKUM PIDANA POSITIF DAN HUKUM PIDANA ISLAM
}

\author{
Alfitra \\ Fakultas Syariah dan Hukum UIN Syarif Hidayatullah \\ Jl. Ir. H. Juanda No. 95 Ciputat, Tangerang, Banten, 15412 \\ e-mail: fitratira@yahoo.co.id
}

\begin{abstract}
Abstrak: Penanganan terhadap persoalan korupsi merupakan tugas berat di setiap negara dalam mencapai good governance. Di Indonesia, sejak bergulirnya reformasi, terjadi peningkatan tindak pidana korupsi dan penyebaran pelakunya semakin meluas. Tulisan ini mencoba memberikan solusi tentang sanksi hukum pemiskinan koruptor, baik dari perspektif hukum pidana positif maupun hukum Islam. Menurut penulis, pemiskinan koruptor yang berarti sebuah hukuman untuk membuat tersangka menjadi miskin akibat aset dan harta benda yang dimilikinya sebenarnya mendapat preseden dari putusan-putusan hakim yang menyita harta koruptor. Dalam hukum pidana Islam, pemiskinan koruptor sebenarnya tidak sejalan dengan konsep 'uqûbah atau penjatuhan sanksi bagi seorang terdakwa. Namun demikian, sebagai sebuah bentuk hukuman takzir berupa denda sejumlah uang yang dituntut oleh Jaksa Penuntut Umum terhadap seorang terpidana kasus korupsi, tampaknya boleh dilakukan.
\end{abstract}

\begin{abstract}
Impoverishment of Corruption Crime in the Perspective of Positive Criminal Law and Islamic Law. Dealing with corruption issue is a tough task of any country in achieving good governance. In Indonesia since reformation era began, there was an increase in the number of corruption crime This paper attempts to provide solution pertaining to sanctions to impoverish corruption crime, both in the perspectives of Islamic positive criminal law and Islamic penal law. According to the author, the impoverishment of corruption crime in the sense of sanction that causes the suspect in the state of poverty due to the fact that their property and asset prescribed in the precedent of the decisions of judges who confiscate criminals. In the Islamic perspective, the impoverishment of the corruption crime as punishment is not in line with a form of punishment named 'uqûbah or impose sanctions for a defendant. Nevertheless, as a form of punishment in the form of fines as ta'zîr, an amount of money demanded by the public prosecutor against a convicted cases of corruption, perceived to be feaseable to be applied.
\end{abstract}

Kata Kunci: korupsi, koruptor, pemiskinan, jinâyah, hukum pidana 


\section{Pendahuluan}

Korupsi yang terjadi di Indonesia saat ini ibarat penyakit kronis yang susah untuk diberantas. Bukti bahwa pemberantasan korupsi merupakan prioritas dari pemerintah bisa dilihat dari rentang waktu yang dibutuhkan. Perjuangan dalam pemberantasan korupsi sudah mencapai lebih dari setengah abad sejak kemerdekaan diproklamirkan oleh SoekarnoHatta. Perjuangan memberantas korupsi tidak mengenal orde pemerintahan, dimulai sejak tahun 1950 an dan sudah melalui empat kali perubahan perundang-undangan dan berbagai instruksi Presiden yang dibentuk khusus untuk memberantas korupsi. Perbuatan korupsi yang telah mengancam sendi-sendi perekonomian negara bisa dilihat baik dalam laporan Ketua Badan Pemeriksa Keuangan (BPK) pada setiap sidang paripurna Dewan Perwakilan Rakyat (DPR) yang melaporkan kasus-kasus korupsi telah merugikan negara. ${ }^{1}$ Korupsi tidak terjadi hanya di pemerintah pusat saja, ${ }^{2}$ melainkan telah merambah ke daerahdaerah baik di lembaga eksekutif maupun legislatif. ${ }^{3}$

Struktur pemerintahan yang diisi oleh pemimpin-pemimnpin yang bermental seperti itu akan menciptakan dan meningkatkan korupsi yang sistematik dan jangkauannya semakin meluas. Bahkan jika kondisi seperti ini dibiarkan tanpa suatu kebijakan yang komprehensif dan berkesinambungan, maka korupsi dapat diklasifikasikan sebagai pelanggaran terhadap hak-hak ekonomi dan sosial seluruh rakyat Indonesia. Pada akhirnya korupsi yang demikian akan membentuk kelompok masyarakat yang sangat koruptif dan lahirnya budaya koruptif bahkan bisa membentuk area koruptif. ${ }^{4}$ Pemberantasan Tindak Pidana Korupsi di Indonesia sudah banyak diatur oleh Undang-undang baik secara umum maupun secara khusus, begitu pun dalam Islam sesungguhnya telah menyediakan seperangkat doktrin yang dapat ditransformasikan sebagai elemen dalam pemberantasan korupsi. Dokrin Islam tidak hanya menyediakan himbauan moral dan sanksi hukuman yang tegas, tetapi juga menawarkan beberapa langkah strategis untuk melakukan pemberantasan tindak pidana korupsi di Indonesia pada khususnya. Jika disimpulkan secara garis besar, dokrin Islam dapat menjelaskan persoalan-persoalan yang akan terjadi. Korupsi berasal dari bahasa

${ }^{1}$ Laporan Badan Pemeriksa Keuangan (BPK) setiap tahun disampaikan dan tidak pernah sekalipun tidak terdapat kasus korupsi.

${ }^{2}$ Beberapa kasus yang menonjol adalah pengadilan kasus korupsi terhadap beberapa exmentri dalam kabinet dan beberapa kasus yang tersangka/terdakwanya anggota Dewan Perwakilan Rakyat

${ }^{3}$ Di Jawa Barat saja bermunculan kasus-kasus korupsi dengan beraneka macam modus operandi, dari kasus kavling gate, Kasus APBD, Mobilisasi di DPRD Subang, Kemudian juga mantan gubernur, bupati/walikota dan pejabat daerah lainnya. Secara nasional mMendagri Gamawan Fauzi mengatakan pada rapat kerja dengan Komite I Dewan Perwakilan Daerah awal bulan Januari lalu bahwa ada 159 kepala daerah yang tersangkut korupsi, 17 orang di antaranya adalah Gubernur. Setiap minggu ada kepala daerah yang diproses dalam kasus korupsi. Bandingkan dengan data KPK yang melansir bahwa sampai Maret 2011 sudah 175 kepala daerah terdiri dari 17 gubernur dan 158 bupati/wali kota yang menjalani pemeriksaan di KPK.

${ }^{4}$ Romli Atmasasmita, Korupsi, Good Governance dan Komisi Anti Korupsi Indonesia (Jakarta: BPHN DepKeh \& Ham, 2002), h. 3. 
latin "coruptus" yang berarti kerusakan atau kebobrokan. Arti secara harafiah korupsi adalah kebusukan, keburukan, dan kebejatan. Korupsi adalah perbuatan buruk seperti penggelapan uang dan penerimaan uang. Adapun arti dari korupsi dapat berupa perbuatan yang buruk (seperti penggelapan uang, dan penerimaan uang sogok). Penyelewengan atau penyalahgunaan uang negara (perusahaan) untuk keuntungan pribadi atau orang lain.

\section{Korupsi dan Social Damage}

Tingginya angka korupsi di Indonesia ${ }^{5}$ telah menyebabkan semua sistem dan sendi kehidupan bernegara rusak karena praktik korupsi telah berlangsung secara merata dan membuat hampir semua elit politik di Indonesia. Jika dibiarkan terus berlangsung dan tanpa tindakan tegas, korupsi akan menggagalkan demokrasi dan membuat negara dalam keadaan bahaya karena kehancuran sistem. Kebijakan nasionalisasi perusahaan asing tahun 1957 menjadi sumber keuangan negara telah menjadi rebutan para pejabat terutama dari kalangan Angkatan Darat. Perusahaan penting dikuasai dan di dalamnya terjadi korupsi besar-besaran. Misalnya kasus Pertamina dan Bulog. Perkembangan korupsi semakin meningkat ketika para birokrat, baik sipil maupun militer terlibat kolusi dalam bisnis yang mengandalkan patron politik baik melalui pemberian lisensi, proyek dan kredit maupun monopoli dan proteksi sampai privatisasi BUMN. Patronasi bisnis ini tumbuh, berkembang, dan mencapai puncaknya dan kini masih terus bertahan. Selain itu di kalangan militer dan kepolisian berkembang jaringan bisnis melalui pendirian yayasan sekalipun proyek-proyeknya sebagian dari negara.

Aparat birokrasi yang seharusnya merupakan abdi negara dan pelayan masyarakat, dalam praktik birokrasinya justru terlibat penghamburan anggaran negara dan membocorkan dana pembangunan. Praktik tidak terpuji dari aparat birokrasi adalah mengembangkan dirinya secara komersial dalam melayani kebutuhan administrasi warga negara, terutama kebutuhan warga negara sebagai pelaku ekonomi berupa merajalelanya pungutan tidak resmi. Kebijakan pemberantasan korupsi melalui proses peradilan tidak berjalan sebagaimana mestinya, karena dunia peradilan dengan pasti telah mengikuti jejak birokrat dan para pegawainya yang korup. Suap menyuap, jual beli perkara dan pemerasan adalah modus operandi dari apa yang disebut dengan "mafia peradilan" yang terus berlangsung hingga sekarang. Aparat penegak hukum dan lembaga peradilan semakin kehilangan kepercayaan dari masyarakat. ${ }^{6}$

${ }^{5}$ Kementrian Dalam Negeri menerima laporan adanya lebih dari 2000 rekening mencurigakan milik pimpinan daerah se-Indonesia serta pejabat daerah lainnya.

${ }^{6}$ Kasus Artalyta dan Urip Santoso serta Jaksa Cyrus Sinaga menunjukan bahwa aparat peradilan telah terkena praktek korupsi yang dengan kasus ini semakin menebalkan keyakinan masyarakat bahwa mafia peradilan memang betul-betul ada. Kasus Hakim Syafrudin menambah daftar aparat penegak hukum yang korup. Lihat juga kasus Hakim Asnun dari PN Tanggerang 
Praktik korupsi yang dilakukan oleh pejabat publik biasanya berhubungan dengan abuse of power dan abuse of officese hingga tepat apa yang dikatakan oleh Lord Acton bahwa power end to corrupt, but absolute power corrupt absolutely. Praktik korupsi sejak zaman dulu selalu berhubungan dengan kekuasaan.

Di era otonomi daerah, praktik korupsi semakin merajalela terutama pada elit lokal. Konsep desentralisasi yang berhenti hanya sebatas pemberian kewenangan kepada pemerintah daerah untuk menyusun kebijakan dan pengelolaan anggaran pada akhirnya menciptakan dominasi kekuasaan oleh elit lokal. Monopoli kewenangan untuk menyusun kebijakan dan mengelola anggaran membuat akses terhadap sumber-sumber daerah hanya kepada elit lokal sangat rawan terhadap korupsi.

Karena praktik korupsi yang terjadi di Indonesia kebanyakan dilakukan oleh pejabat publik, tidak mengherankan apabila penegakan hukum terhadap tindak pidana korupsi tampak tersendat-sendat dan bahkan sering terjadi stagnasi sehingga menimbulkan citra yang negatif terhadap aparat penegak hukum pada khususnya, dan pemerintah pada umumnya. $^{7}$

Dari sudut pandang pendekatan yuridis yang diperlukan, dasar hukum untuk memberantas korupsi di Indonesia sudah memadai, karena sudah diberlakukannya sejumlah peraturan perundang-undangan yang sifatnya anti korupsi antara lain Undang-Undang Nomor 28 Tahun 1999 tentang Penyelenggaraan Negara yang Bersih dari Korupsi, Kolusi dan Nepotisme; Undang-Undang Nomor 11 tahun 1980 tentang Pemberantasan Suap; Undang-Undang Nomor 31 tahun 1999 tentang Pemberantasan Tindak Pidana korupsi Jocto Undang-Undang Nomor 20 tahun 2001 tentang Perubahan atas Undang-Undang Nomor 31 tahun 1999; Intruksi Presiden Nomor 5 Tahun 2005; Peraturan Pemerintah Nomor 30 Tahun 1980 tentang Disiplin Pegawai Negeri; dan Inpres Nomor 9 Tahun 2011 tentang Rencana Aksi Pencegahan dan Pemberantasan Korupsi.

Dengan demikian, sebenarnya tidak ada halangan bagi aparat penegak hukum untuk mengadili kasus-kasus korupsi. Political will dari pemerintah tentang pemberantasan korupsi sudah dikumandangkan, tinggal sejauh mana tingkat profesionalisme dan sekaligus integritas aparat penegak hukum menjalankan amanat ini. Hukum yang baik dengan aparat pelaksana yang buruk akan menghasilkan yang buruk, tetapi hokum yang buruk dengan aparat yang baik akan menghasilkan sesuatu yang baik.

\section{Korupsi Wujud Perbuatan Anomie of Success}

Menurut istilah ekonomi, korupsi menyebabkan alokasi sumber daya kearah yang salah dan mengendorkan pihak swasta untuk berinvestasi. Korupsi juga mempunyai pengorbanan sosial yang berarti, korupsi menimbulkan budaya melarat dan kriminalitas,

${ }^{7}$ Kusuma M. Tegaknya supermasi Hukum. Remaja Rosdakarya (Bandung: t.p., 2001), h 33. 
serta merampas hak kaum miskin untuk memperoleh manfaat dari sumber daya negara. Lebih jauh lagi pengorbanan politik, korupsi dapat menimbulkan keruntuhan, korupsi menghancurkan kepercayaan rakyat terhadap pemerintah dan menggerogoti legitimasi lembagalembaga politik).

Sama halnya dengan pendapat ini adalah apa yang dikemukakan oleh Romli Atma Sasmita yang mengatakan bahwa dalam sejarah bangsa-bangsa, tiga kata kunci yaitu korupsi, kolusi dan nepotisme (KKN) merupakan sumber runtuhnya suatu rezim. ${ }^{8}$ Mantan Wakil Presiden Amerika Serikat Algore menegaskan antara lain: "The reisnoquestion that aswemovein toglobalage, foreign corrupt practices threatento undermine both the growt handthestabili tyofour global trade and financial system. Now here are the consequencesmor evident than inemerging and developing economies. The Financial crisisin Russia and Asia havec learly been deepenedasa results of cronyism and corruption". ${ }^{9}$

Menurut Badan Pemeriksa Keuangan Austria yang dibahas dalam kongres INTOSA (Perhimpunan BPK sedunia) keXVI di Montevideo Uruguay bulan November 1998 pengertian korupsi mencakup ${ }^{10}$ bribery and extortion (penyuapan dan pemerasan): fraud, embezzlement, and theft (kecurangan, penggelapan dan pencurian); misapprovition of public resources (penyelewengan sumber daya negara); under vapor in exchange for gain (memberikan kebaikan untuk memperoleh imbalan keuntungan); abuse of office (penyalahgunaan jabatan atau wewenang); nepotism; over or under invoicing (melebihkan atau merendahkan nilai faktur); under changing of taxes and duties; menghindarkan pajak dan penyelundupan; dan unfair requirement.

Para sarjana banyak juga yang mengemukakan pendapatnya tentang pengertian korupsi. Menurut David HB ailey, korupsi adalah perangsang (seorang pejabat pemerintah) suapan agar melakukan pelanggaran kewajibannya. ${ }^{11}$ Menurut Purwadarminta, korupsi adalah perbuatan buruk seperti penggelapan uang, penerimaan uang sogok dan sebagainya. ${ }^{12}$ Secara umum korupsi ini berkaitan dengan perbuatan merugikan kepentingan publik atau masyarakat luas untuk keuntungan pribadi atau kelompok tertentu.

Dapat disimpulkan bahwa sesungguhnya korupsi sebagai suatu istilah, mempunyai pengertian sangat luas. Dengan demikian pendekatan yang dapat dilakukan terhadap masalah korupsi bermacam-macam pula, pendekatan sosiologis akan lain artinya dengan pendekatan normatif, begitu pula dengan pendekatan politik atau ekonomi. Sebagai contoh Syed Hussein

${ }^{8}$ Romli Atmasasmita, Reformasi Hukum, Hak Asasi Manusia \& Penegakan Hukum (Bandung: Mandar Maju, 2001), h. 77.

${ }^{9}$ Ibid.

${ }^{10}$ Bandingkan dengan pengertian korupsi menurut Undang-Undang Nomor 31 tahun 1999 Jo Undang-Undang Nomor 20 tahun 2001, dari mulai Pasal 2 sampai dengan pasal 14.

${ }^{11}$ David H Bailey, "Akibat Korupsi pada Bangsa-Bangsa yang Sedang Berkembang," dalam Mochtar Lubis (ed.), Bunga Rampai Korupsi (Jakarta: LP3ES, 1985), h. 86-90.

${ }^{12}$ Purwadarminta, Kamus Umum Bahasa Indonesia (Jakarta: Depdikbud, 1996). 
Alatas ${ }^{13}$ memasukkan nepotisme dalam kelompok korupsi, yang tentu saja sangat sulit mencari normanya dalam hukum pidana.

Unsur-unsur korupsi selalu berkaitan dengan pemberian seseorang kepada pejabat negara dengan maksud untuk mempengaruhinya agar memberikan perhatian istimewa kepada kepentingan si pemberi. Fenomena lain yang dapat dipandang sebagai korupsi adalah nepotisme berupa pertimbangan saudara, teman atau rekan politik dan jabatan-jabatan penting lainnya tanpa melihat jasa mereka maupun konsekuensi pada kesejahteraan publik. Jadi, nepotisme adalah suatu kebijakan yang didasarkan atas hubungan keluarga yang muaranya bertujuan untuk mendapat keuntungan baik bersifat keuangan atau bukan. Ada empat fenomena yang tercakup dalam istilah korupsi, yaitu penyuapan, pemerasan, gratifikasi dan nepotisme. Selanjutnya unsur korupsi yang berhubungan dengan fenomena tadi adalah ${ }^{14}$ bahwa pelaku biasanya mempunyai pengaruh yang kuat, baik status ekonomi maupun status politik.

Meraja lelanya kasus korupsi di kalangan pejabat publik karena akuntabilitas publik, prinsip tranparansi dan rasa tanggungjawab dalam mengemban amanat rakyat tidak dipegang teguh oleh pejabat publik tersebut. Prinsip anomie ofs uccess yang diterapkan oleh penyelenggara negara sangat vulgar. Karena itu, tepat sekali apa yang dikemukakan oleh IS Susanto bahwa masa krisis yang melanda Indonesia merupakan buah kebijakan yang penuh dengan korupsi, kolusi, dan nepotisme yang dilakukan oleh pelaku bisnis, birokrasi serta elit penguasa. ${ }^{15}$ Dalam rangka penanggulangan dan pemberantasan korupsi, kebijakan yang harus ditempuh bukanlah kebijakan yang sifatnya fragmentaris dan parsial saja.

Selama ini kebijakan yang ditempuh lebih terfokus kepada upaya melakukan pembaharuan perundang-undangan (lawreform) pada hal masalah korupsi penuh dengan berbagai kompleksitas. Seyogyanya ditempuh pendekatan integral tidak hanya melakukan law reform, tetapi disertai dengan social, economic, political, cultural, moral, dan administrative reform. ${ }^{16}$ Dalam konteks ajaran Islam yang lebih luas, korupsi merupakan tindakan yang bertentangan dengan prinsip keadilan (al-'adalah), akuntabilitas (al-amanah) dan tanggungjawab. Korupsi dengan segala dampak negatifnya yang menimbulkan berbagai distorsi terhadap kehidupan negara dan masyarakat dapat dikategorikan termasuk perbuatan fasad, kerusakan di mukabumi yang dikutuk oleh Allah Swt. ${ }^{17}$

${ }^{13}$ Syeid Hussein Alatas, Sosiologi Korupsi: Sebuah Penjelajahan dengan Data Kontemporer (Jakarta: LP3ES, 1983), h. 11-14.

${ }^{14}$ Bandingkan dengan anatomi kejahatan ekonomi, sebab pada hakikatnya korupsi termasuk dalam kejahatan ekonomi, a) pengawasan atau sifat tersembunyinya maksud dan tujuan kejahatan; b) keyakinan si pelaku terhadap kebodohan dan kesembronoan korban; c) penyembunyian pelanggaran. Lihat Muladi dan Barda nawawi Arief, Bunga Rampai Hukum Pidana (Bandung: Alumni, 1992), h. 5-6.

${ }^{15}$ IS Susanto, "Kejahatan Korupsi di Indonesia: Produk Kebijakan Orde Baru," Pidato Pengukuhan Guru Besar Undip, Semarang, 1999, h. 2.

${ }^{16}$ Barda Nawawi Arief, Kapita Selekta Hukum Pidana (Bandung: Citra Aditya, 2003, h. 66.

${ }^{17}$ Azyumardi Azra, "Agama dan Pemberantasan Korupsi," dalam Pramono U. Tanthowi, 
Penegakan hukum terhadap kasus korupsi selama ini bergantung kepada manajemen pemerintah (management by order) dan lebih ditekankan pada kebijakan sesaat, sehingga sasaran kebijakan yang akan dicapai seolah-olah samar-samar. Dalam kaitan ini sudah saatnya digunakan manajemen sistem dengan mengurangi tolok ukur kuantitatif sebagai ukuran keberhasilan penegakan hukum, khususnya terhadap korupsi. ${ }^{18}$ Keberhasilan terhadap penanggulangan praktik korupsi, di samping sangat tergantung pada ketersediaan instrumeninstrumen hukum berupa ketersediaan aturan main yang jelas, perlu juga suatu komitmen yang jelas dan tegas dari aparat penegak hukum serta tingkat profesionalismenya. ${ }^{19}$ Romli Atma Sasmita mengatakan untuk mempersiapkan usaha pemberantasan korupsi yang efisien dan efektif pemerintah telah menyusun strategi nasional pemberantasan korupsi yang bertumpu pada empat pendekatan yaitu pendekatan hukum, pendekatan budaya, pendekatan ekonomi, dan pendekatan sumber daya manusia dan sumber daya lingkungan. ${ }^{20}$

\section{Rekomendasi dalam Penegakan Hukum}

Sulitnya memberantas korupsi dan banyaknya kasus-kasus yang diputus pengadilan tetapi tidak memuaskan rasa keadilan masyarakat berasal dari lemahnya penegakan hukum. Dalam penegakan hukum, paling tidak ada tiga unsur yang harus diperhatikan yaitu unsur hukum, kualitas pelaksana, dan faktor lingkungan sosial. Di antara ketiga faktor tadi faktor kualitas pelaksana (aparat penegak hukum) merupakan faktor penentu. ${ }^{21}$ Bagir Manan mengemukakan, ada berbagai syarat yang harus dipenuhi untuk penegakan hukum yang adil dan berkeadilan. ${ }^{22}$ Pertama, aturan hukum yang akan ditegakkan. Penegakan hukum yang adil atau berkeadilan akan tercapai apabila hukum yang akan ditegakkan adalah benar dan adil. Kedua, pelaku penegakan hukum. Pelaku penegakan hukum dapat disebut sebagai kunci utama penegakan hukum yang adil dan berkeadilan. Di tangan pelaku penegakan hukum aturan hukum yang bersifat abstrak menjadi konkret, berlaku terhadap pencari keadilan. Ketiga, lingkungan sosial sebagai tempat hukum berlaku.

Membasmi Kanker Korupsi (Jakarta: t.p., 2004), h. 244-245. Lihat juga Q.S. al-Ma'idah/5: 33" sesungguhnya pembalasan terhadap orang-orangyang memerangi Allah dan Rasul-Nya dan membuat kerusakan dimuka bumi, hanyalah mereka dibunuh atau disalib, atau dipotong tangan dan kaki mereka (dengan menyilang) atau dibuang dari negeri (tempat kediamannya). Yang demikian itu sebagai suatu penghinaan untuk mereka didunia, dan diaherat mereka peroteh siksaan yang besar.

${ }^{18}$ Romli Atmasasmita, "Pemberantasan Korupsi Tergantung Kepada Presiden," dalam Pikiran Rakyat, 11 Oktober 2004.

${ }^{19}$ Barda Nawawi Arief, Bunga Rampai Kebijakan Hukum Pidana (Bandung: Citra Aditya, 1996), h. 112.

${ }^{20}$ Atmasasmita, "Pemberantasan Korupsi Tergantung Kepada Presiden," h. 29.

${ }^{21}$ Soerjono Soekanto, Sosiologi Hukum Dalam Masyarakat (Jakarta: Rajawali Press, 1976), h.9

${ }^{22}$ Bagir Manan, "Penegakan Hukum yang Berkeadilan," (Kumpulan bahan Kuliah Pengembangan Sistem Hukum Indonesia Abad XXI, Program Pascasarjana Universitas Padjadjaran, Bandung, 2003), h. 12-14. 
Penegakan hukum adalah the detection and punishment of violation of the law. This term is not limited to enforcemen to criminal law. ${ }^{23}$ Menurut Jimly as-Siddieqy, penegakan hukum adalah proses dilakukannya upaya tegaknya atau berfungsinya norma-norma hukum secara nyata sebagai pedoman perilaku dalam lalu lintas atau hubungan-hubungan hukum dalam kehidupan bermasyarakat dan bernegara. ${ }^{24}$ Berdasarkan kajian dari berbagai sumber, didapatkan sejumlah cara bagaimana memberantas korupsi: pertama, sistem penggajian yang layak kepada aparat pemerintah; kedua, larangan menerima suap dan hadiah. Hadiah dan suap yang diberikan seseorang kepada aparat pemerintah pasti mengandung maksud tertentu; ketiga, perhitungan kekayaan para pejabat; keempat, keteladanan dari pemimpin. Pemberantasan korupsi akan berhasil bila para pemimpin bersih dari korupsi; kelima, hukuman yang setimpal dan tanpa diskriminasi; dan keenam adalah pengawasan dari masyarakat. ${ }^{25}$

Selain itu, seyogyanya sistem pembuktian terbalik lebih banyak digunakan dalam mengadili perkara koruspi. ${ }^{26}$ Asas pembalikan beban pembuktian terbalik merupakan suatu sistem yang berada di luar kelaziman teoritis ${ }^{27}$ pembuktian dalam hukum acara pidana. Dalam sistem hukum anglo saxon maupun eropa continental, beban pembuktian tetap berada pada jaksa penuntut umum. Hanya saja, dalam kasus-kasus tertentu diperkenankan penerapan dengan mekanisme yang diferensial, yaitu sistem pembalikan beban pembuktian atau dikenal sebagai reversal of burden proof (omkering van bewisjlast). Alasan penggunaan asas pembalikan beban pembuktian terbalik dalam kasus korupsi adalah bahwa korupsi merupakan extra ordinary crime, maupun seriousness crime sehingga kejahatan korupsi sering dikatakan sebagai "beyond the law" karena pelakunya melibatkan kalangan ekonomi tinggi dan birokrasi tingkat atas maupun kalangan politisi dan bentuk perbuatan korupsi ini "untouchab leby the law". Dengan demikian, mengingat karakteristik dari korupsi seperti ini, maka memerlukan penanganan yang luar biasa (extra ordinary enforcement).

\section{Implementasi Sanksi Pidana Pemiskinan Koruptor di Indonesia}

Pemiskinan koruptor merupakan langkah dan terobosan baru dalam memberantas korupsi. Banyak terdakwa kasus korupsi masih dapat menikmati banyak fasilitas, meskipun telah berstatus sebagai narapidana. Ketika pidana penjara sudah dirasakan tidak efektif

\footnotetext{
${ }^{23}$ Bryan Gunner, Black Law Dictionary (Minnesota: Seven Edt.West Group, St Paul, 1999).

${ }^{24}$ Jimly Assiddiqie, "Penegakan Hukum, Keadilan dan Hak Asasi Manusia," dalam Jurnal Keadilan, Vol. 2 Nomor 2 Tahun 2002.

${ }^{25}$ Muhammad Ismail Yusanto, "Islam dan Jalan Pemberantasan Korupsi," http://www.esyariah.net. diakses tanggal 19 Maret 2005.

${ }^{26}$ Alfitra, "Modus Operandi Tindak Pidana khusus di Luar KUHP," dalam Penebar Swadaya, Jakarta, 2014, h. 102.

${ }^{27}$ Herbert Packer, The Limits of Criminal Sanction (California: Stanford University Press, t.t.), h. 30 .
} 
dan tidak menjerakan koruptor, perlu terobosan baru dan tindakan konkrit. Sanksi pidana pemiskinan koruptor dirasa perlu diterapkan dalam beberapa kasus korupsi dengan harapan dapat menimbulkan efek jera bagi pelaku tindak pidana korupsi. ${ }^{28}$ Pemiskinan koruptor di Indonesia dapat dilihat nyata dalam kasus Angelina Sondakh. Angelina Sondakh didakwakan terkait kasus korupsi penggiringan anggaran di Kemenpora dan Kemendiknas senilai 3 (tiga) miliar rupiah. Dalam putusan pertama di Pengadilan Tipikor Jakarta, Angelina Sondakh divonis dengan hukuman penjara 4 tahun 6 bulan. Vonis hakim ini jauh lebih ringan dari tuntutan Jaksa Penuntut Umum (JPU) yang menuntut Angelina Sondakh. Dengan hukuman 12 (dua belas) tahun penjara. Angelina Sondakh kemudian mengajukan kasasi yang ternyata hukumannya justru diperberat dari 4 tahun 6 bulan menjadi 12 (dua belas) tahun penjara.

Selain itu juga dalam rangka pemiskinan koruptor, Angelina Sondakh didapuk membayar uang pengganti sebesar Rp 12,58 miliar dan USD 2,35 juta. Walau sebenarnya, putusan kasasi oleh Hakim Agung Artidjo merupakan tuntutan Jaksa Penuntut Umum (JPU) yang didakwakan kepada Angelina Sondakh sebelumnya. Putusan Hakim Tipikor yang menghukumnya lebih rendah dari tuntutan Jaksa dan putusan kasasi yang dipimpin oleh Hakim Agung Artidjo mengukuhkan tuntutan JPU tersebut. Vonis hukuman pembayaran uang pengganti sebesar Rp 12,58 miliar dan USD 2,35 juta dalam kasus Angelina Sondakh ini tentu jauh dari angka besaran uang yang dikorupsi Angelina Sondakh. Angelina Sondakh terbukti melakukan korupsi sebesar 3 (tiga) miliar rupiah, namun hukuman pembayaran uang pengganti sangat jauh dari besaran uang yang telah dikorupsi. Dari kasus Angelina Sondakh tersebut, sudah menunjukkan iktikad dan juga tekad dari penegak hukum untuk memberantas korupsi dengan menghukum koruptor seberat-beratnya dan juga pemiskinan koruptor yang telah mengeruk uang rakyat dan menjarahnya. Pemiskinan koruptor sangat jelas terlihat dalam kasus Angelina Sondakh tersebut.

Sanksi pidana pemiskinan koruptor belum mendapatkan konsep yang jelas dan mapan, bahkan belum ada persamaan persepsi diantara para pegiat anti korupsi mengenai konsep pemiskinan ini. Banyak berbagai pihak yang menyatakan setuju dengan adanya pemiskinan koruptor, namun disisi lain juga terdapat berbagai pihak yang menyatakan tidak setuju dengan adanya pemiskinan koruptor bagi pelaku tindak pidana korupsi. Pemiskinan koruptor yang selama ini dilakukan hanya dengan perampasan aset hasil tindak pidana korupsi. Perampasan aset tersebut dengan perampasan seluruh benda-benda yang merupakan hasil dari tindak pidana korupsi dan/atau dengan pembayaran uang pengganti yang jumlahnya sesuai dengan kerugian keuangan negara dari tindak pidana korupsi. Hal tersebut tidak dapat dikatakan memiskinkan koruptor karena koruptor masih dapat dengan bebas menggunakan aset yang dimilikinya yang tidak dirampas. ${ }^{29}$

${ }^{28}$ Indriyanto Seno Adji. Korupsi dan Penegakan Hukum (Jakarta: Media, 2009), h. 21.

${ }^{29}$ Alatas, Korupsi, Sifat, Sebab dan Fungsi (Jakarta: LP3ES, 1987), h. 7. 


\section{Pemiskinan Koruptor dalam Konteks Hukum Positif}

Korupsi telah berlangsung secara sistemik dan meluas sehingga tidak hanya kerugian keuangan negara, tetapi juga melanggar hak-hak sosial dan ekonomi masyarakat. ${ }^{30}$ Jenis korupsi di Indonesia tidak hanya sekedar mengandung aspek ekonomis tetapi juga korupsi jabatan, korupsi kekuasaan, korupsi politik, korupsi nilai-nilai demokrasi, dan korupsi moral, tetapi yang lebih banyak terjadinya korupsi adalah kejahatan yang dilakukan oleh pejabat publik. Sebagai sebuah extra ordinary crime korupsi yang dilakukan oleh pejabat publik sudah mendapat perhatian Perserikatan Bangsa-Bangsa.

Dalam resolusi tentang corruption in government yang diterima Kongres Perserikatan Bangsa-Bangsa ke 8 mengenai the prevention of crime and the treatment of offenders tahun 1990 antara lain dinyatakan bahwa korupsi di kalangan pejabat publik dapat menghancurkan efektifitas sosial dari semua jenis program pemerintah, dapat menghambat pembangunan dan menimbulkan korban individual maupun kelompok. Kewenangan melakukan penyidikan tindak pidana korupsi kepada tiga lembaga penegakan hukum yang ada sekarang yaitu Polisi, Jaksa dan KPK seharusnya memperlihatkan prestasi yang luar biasa dalam memberantas korupsi, tetapi dalam praktik sering terjadi tumpang tindih penyidikan terutama antara polisi dan jaksa. Ini akan menimbulkan kesan bahwa the due process of law tidak akan berjalan yang pada akhirnya akan merugikan pencari keadilan dan masyarakat. ${ }^{31}$

Apabila melihat tantangan pemberantasan korupsi dan penyakit korupsi yang semakin meluas, sungguh ironis apabila antara penegak hukum saling menjatuhkan atau mengkerdilkan. Bukankah tugas penegakan hukum itu adalah menegakkan hukum dan keadilan untuk setiap orang?. Semestinya antara semua penegak hukum terjalin sinkronisasi dan kekompakan dalam pemberantasan korupsi. Dengan menata kelembagaan dan kewenangan dari ketiga lembaga penegakan hukum ini, akan dicapai mekanisme yang jelas dan tumpang tindih kewenangan akan terhindar. Pengaturan kewenangan tersebut bisa dilakukan dengan membagi bahwa kejahatan-kejahatan umum disidik oleh polisi, sedangkan tindak pidana korupsi disidik oleh KPK, selanjutnya kejaksaan hanya bertugas melakukan penuntutan saja, atau tetap mempertahankan kondisi ketiga lembaga penegakan hukum ini seperti sekarang tetapi dengan menata mekanisme yang ada sekarang secara jelas.

Sebetulnya masyarakat masih membutuhkan ketiga lembaga penegakan hukum ini, tetapi dengan syarat bahwa mereka harus bekerja demi melindungi masyarakat dari tindak pidana kejahatan bukan mereka saja masyarakat supaya menjadi terdakwa. ${ }^{32}$ Di tengah kesulitan hidup yang dialami masyarakat seharusnya lembaga penegakan hukum ini bahu membahu memberantas kejahatan dengan fungsi masing-masing. Mereka seharusnya

\footnotetext{
${ }^{30}$ Edi Setiadi, Hukum Pidana Ekonomi (Bandung: Fakultas Hukum UNISBA, 2004), h. 11.

${ }^{31}$ Muhammad Ismail Yusanto, "Islam dan Jalan Pemberantasan Korupsi," http//www.esyariah.net, Diakses Tanggal, 19 Maret 2010.

${ }^{32}$ Topo Santoso, Membumikan Hukum Pidana Islam: Penegakan Syariah dalam Wacana dan Agenda (Jakarta: Gema Insani, 2003), h. 23.
} 
menjadi pahlawan dalam memberantas korupsi bukan menjadi pengkhianat. Pemiskinan koruptor berhubungan dengan masalah pemidanaan. Herbert Packer mengemukakan bahwa ada dua pandangan konseptual yang masing-masing mempunyai implikasi moral yang berbeda satu sama lain, yaitu pandangan retributif dan pandangan utilitarian. Pandangan retributif mengandaikan pemidanaan sebagai ganjaran negatif terhadap perilaku menyimpang yang dilakukan oleh warga masyarakat sehingga pandangan ini melihat pemidanaan hanya sebagai pembalasan terhadap kesalahan yang dilakukan atas dasar tanggungjawab moralnya masing-masing. ${ }^{33}$ Dalam memberantas kejahatan korupsi tujuan dan pola pemidanaan semestinya dirumuskan dengan komprehensif, ancaman pidana kurungan badan dan denda serta uang pengganti ternyata tidak membuat kasus korupsi menurun. Seolah-olah ancaman pidana yang tercantum dalam undang-undang pemberantasan korupsi tidak menimbulkan efek jera apalagi sebagai alat pencegah. Perlu dipikirkan langkah konkrit supaya aset negara yang dikorupsi bisa diambil kembali.

Sebelum sampai pada pemiskinan koruptor yang tentu saja ini berhubungan dengan kebijakan kriminal yang ditempuh, terlebih dahulu akan diuraikan langkah-langkah penegakan hukum untuk memberantas kejahatan korupsi. Salah satunya adalah apa yang disebut dengan beban pembuktian terbalik. Pembuktian terbalik dalam perkara pidana adalah langkah hukum luar biasa. Doktrin hukum pidana dan konvensi internasional perlindungan hak asasi manusia melarang pembuktian terbalik karena bertentangan dengan asas non self incrimination dan asas presumption of innocence. Akan tetapi karena kejahatan korupsi adalah extra ordinary crime, doktrin pembuktian terbalik ini diperkenalkan dalam undangundang tindak pidana korupsi walaupun beban pembuktian tetap ada pada jaksa dan jaksa berkewajiban membuktikan kesalahan pelaku.

Secara sederhana dan praktis, langkah pencegahan terjadinya tindak pidana koupsi adalah dengan mengefektifkan Undang-undang Nomor 28 tahun 1999 tentang Penyelenggara Negara yang Bersih dan Bebas dari KKN yang dilengkapi dengan membuat undang-undang lain yang bersifat refresifnya sehingga bisa melengkapi Undang-Undang nomor 28 tahun 1999 dan Undang-Undang nomor 8 tahun 2010 tentang Pencegahan dan Pemberantasan Tindak Pidana Pencucian Uang (money laundring), sebelumnya dengan undang-undang Nomor 15 tahun 2002. Verifikasi dan klarifikasi laporan harta kekayaan ini sangat membantu dalam melaksanakan pembuktian terbalik sekaligus dapat "memiskinkan koruptor" karena beban pembuktian terbalik dapat terlaksana dan berhasil apabila didukung oleh data harta kekayaan penyelenggara negara yang akurat. Pelaporan harta kekayaan penyelenggara negara dapat merupakan entri point bagi jaksa atau hakim untuk membuat tuntutan dan membuat vonis sehingga perampasan aset dari hasil kejahatan korupsi dapat membawa hasil yang signifikan bagi negara. ${ }^{34}$

\footnotetext{
${ }^{33}$ Soerjono Soekanto, Sosiologi Hukum dalam Masyarakat (Jakarta: Rajawali Press, 1979), h. 75.

${ }^{34}$ Nurjana I.G.M., Sistem Hukum Pidana dan Bahaya Laten Korupsi (Yogyakarta: Pustaka Pelajar, 1983), h. 55.
} 
Langkah yuridis yang harus ditempuh dalam memiskinkan koruptor adalah membuat Undang-Undang Perampasan Aset Kejahatan, nantinya undang-undang ini harus menegaskan bahwa perampasan aset hasil kejahatan dapat dilakukan melalui dua jalur yaitu: jalur penal sebagai primum remedium, dan jalur perdata sebagai ultimum remedium. Pelaksanaannya dilakukan secara komplementer. Selain itu dalam RUU KUHP harus dicantumkan denda yang berlipat-lipat dari nilai harta yang dikorupsi. Langkah berikutnya adalah melalui kerjasama intenasional misalnya program Stolen Asset Recovery Initiative yang digagas Bank Dunia sehingga aset koruptor yang berada di luar negeri dapat kembali lagi kepada pemerintah (banyak contoh program Stolen ini berhasil dilakukan misalnya di negara Amerika Latin). Hal lain yang harus diperhatikan pemerintah adalah mendayagunakan Undang-Undang Nomor 7 tahun 2006 tentang Ratifikasi Konvensi PBB Anti Korupsi tahun 2003 (United Nation Convention Againts Corruption/UNCAC) sehingga pemerintah bisa mengakses bantuan internasional bagi usaha-usaha perampasan, pembekuan, dan pengembalian aset kejahatan ke negara, termasuk membawa kembali koruptor yang kabur keluar negeri seperti yang ada di Singapura, China dan Taiwan.

\section{Pemiskinan Koruptor dalam Konteks Hukum Islam}

Dalam sejarah Islam telah banyak contoh bagaimana para pejabat yang notabene sahabat Nabi memegang amanah jabatannya dengan tidak menerima suap. Hadis riwayat Abû Dâwûd menegaskan bahwa "laknat Allah terhadap penyuap dan penerima suap." Tentang hadiah kepada aparat pemerintah, Rasullullah berkata "hadiah yang diberikan kepada para penguasa adalah suht (haram) dan suap yang diterima hakim adalah kufur." (HR. Imam Ahmad). Sebagai agama yang sempurna, Islam tidak hanya mengatur hubungan makhluk dengan sang Allah Swt., tetapi juga mengatur manusia dengan manusia, bahkan manusia dengan alam. Dalam beberapa hal, kualitas hubungan antara manusia merupakan refleksi dari kualitas hubungan manusia dengan Tuhannya. Karena itu, Islam menyajikan beberapa prinsip agar hubungan antar manusia menjadi harmonis dan beradab.

Inilah yang kemudian disebut sebagai 'alaqah ijtima'iyah dengan semestinya agar tercipta masyarakat yang harmonis dan beradab di antaranya adalah sebagai berikut. Pertama, amanah, secara etimologis berati “ jujur dan lurus” sedangkan dalam arti terminologis syar'i, sesuatu yang harus dijaga dan disampaikan kepada yang berhak menerimanya. Karena pada dasarnya amanah adalah sesuatu yang diserahkan kepada orang lain disertai dengan rasa aman dari pemberinya, karena kepercayaan bahwa apa yang diamatkan itu akan aman dan dipelihara dengan baik, serta keberadaannya aman di tangan yang diberi amanat itu. ${ }^{35}$ Orang yang mampu melaksanakan amanah disebut al-hâfizh, al-âmîn, dan al-wafy, sedangkan orang yang menyanyiakannya al-khain (pengkhianat). Di dalam al-Qur'an, kata amanah sering dikaitkan dengan ciri-ciri atau karakteristik sejati

${ }^{35}$ Tim Editor Kompas, "Belajar dari Cina: dalam Buku Sorga Para Koruptor," dalam Kompas, 2004. 
orang-orang yang beriman. ${ }^{36}$ Karena sifat ini senantiasa melekat dalam setiap aspek kehidupan orang beriman baik dalam bidang muamalah. Rasyid Ridha ketika menafsirkan Q.S. al-Baqarah/2: 283 menegaskan bahwa yang dimaksud amanah pada ayat tersebut bersifat umum, tidak hanya terkait masalah utang-piutang dan perdagangan saja, tetapi mencakup tugas-tugas lain. Apabila sesorang menerima tugas baik dari pemerintah maupun swasta, ia wajib melaksanakan amanah dengan sebaik-baiknya disiplin, dalam pengelolaan keuangan, dan sebaik-baiknya ia tidak boleh berkhianat sedikit pun sebab Allah senantiasa mengawasinya. Terlebih lagi jika peng-khianat itu dilakukan kepada Allah dan Rasul-Nya, maka orang yang dibei amanah harta wajib menyampaikannya kepada yang berhak menerimanya dan orang yang diberi amanah jabatan wajib melaksanakanya dengan sebaik-baiknya dengan tidak menyalahgunakannya untuk kepentingan pribadi atau keluarga, seperti korupsi, kolusi, dan nepotisme. Karena itu, agar tidak terjadi penyalahgunaan kekuasaan dan pengkhianatan, maka prinsip profesionalisme dan kualifikasi lainya sebagai penerima harus dilakukan secara ketat.

Kedua, amanah adalah sumber keadilan, dan keadilan sumber keamanan dan kebahagiaan. Setelah Allah menyuruh manusia menyampaikan amanah, kemudian memerintahkan manusia agar menegakkan keadilan. Firman Allah menegaskan bahwa menegakkan dan menjunjung tinggi keadilan adalah wajib bagi setiap manusia, apalagi bagi aparat penegak hukum. Karena itu, perintah menegakkan hukum disebut dalam alQur'an secara berulang-ulang sekalipun dalam ungkapan yang berbeda-beda. Misalnya menggunakan kata al-'adl. Kata al-'adl berasal dari kata 'adala-ya'dilu-'adlan. Namun menurut Ibn al-Atsir, kata tersebut dapat dibaca dengan kasrah pada huruf 'ain: al-'idl yang artinya "menyamakan". Pada awalnya, kata al-idl berarti "separuh muatan yang ada pada salah satu dari dua sisi punggung unta".

Sedangkan menurut istilah syar'iyyah, sebagian ulama berpendapat al-'adl adalah menjauhkan diri dosa besar seperti: zina, mencuri, membunuh tanpa hak serta menjauhkan diri dosa kecil, seperti makan dan buang air kecil di jalan. Sebagai ulama yang lain memahaminya sebagai memperlakukan dua orang yang berperkara dengan perlakuan yang sama dan tidak mengutamakan salah seorang yang berpekara tersebut sedikitpun. Karena itu, al-Râzî dengan mengutip pendapat al-Syâfi'i mengatakan bahwa seorang hakim harus memperlakukan kedua orang yang berperkara dengan perlakuan yang sama dalam lima hal: ketika masuk menghadap hakim,ketika mereka duduk menghadap hakim, ketika hakim menghadapi mereka, ketika hakim mendengarkan mereka, dan ketika hakim memutuskan perkara bagi mereka yang dimaksud dengan persamaan adalah dalam masalah lahiriah, bukan hati. Apabila hati cenderung kepada salah satu di antara yang berperkara, maka tidaklah menjadi masalah,karena tidak mungkin menghindarinya. ${ }^{37}$

\footnotetext{
${ }^{36} J$ Jeremy Pope, Strategi Memberantas Korupsi (Jakarta: TII dan Yayasan Obor Indonesia 2003).

${ }^{37}$ Bambang Widjojanto, "Peran Masyarakat dalam Menghilangkan Budaya Korupsi di Indonesia," makalah disampaikan pada acara Halakah Tarjih Muhammadiyah Solo 2005.
} 
Konsep atau terminologi yang sering dihubungkan korupsi karena melihatnya sebagai pengkhianatan atas amanat yang seharusnya dijaga di antaranya sebagai berikut. Pertama, ghulul, secara leksikal dimaknai akhdzu al-syai wa dassahu fi mata'ibi, mengambil sesuatu dan menyembunyikannya dalam hartanya (dalam hukum pada kata rasya-yarsyu-risywatan yang bermakna al-ju'l yang berarti upah, hadiyah, pemberian atau komisi). Kedua, ghasab (mengambil paksa hak orang lain) menurut Abû Hanifah dan Abû Yûsuf, ghasab tidak dapat terealisasi kecuali dengan memindahkan yang dapat diambil dari tempatnya semula ke tempat lain. Ketiga, saraqah (pencurian) perpindahan hak atas harta secara melawan hukum dan praktek ini sudah lama dikenal kata pencurian pasal 362 KUHP. Keempat, intikhab dalam kitab fikih (akhdzu syai mughalabatah) merampas atau menjambret. Kelima, ikhtilash (gatfu syai jiharan bi hadhrat shahibihifi ghaflah mimhu wal harab bih), mencopet/ mengutil. Keenam, aklu suht (makan barang haram) dengan asal kata sesuatu yang membinasakan, sedangkan sesuatu yang haram pasti membinasakan pelakunya. Ada juga yang menyamakan kata tersebut melukiskan binatang yang sangat rakus dalam melahab makanan. Seseorang yang tidak peduli dari mana memperoleh harta, maka ia dipersamakan dengan binatang yang melahab segala macam makanan, sehingga pada akhirnya binasa oleh perbuatannya sendiri.

Dalam perspektif Islam, pemiskinan terhadap koruptor sebagai hukuman dapat dianggap sebagai sebuah bentuk hukuman takzir berupa denda sejumlah uang yang dituntut oleh Jaksa Penuntut Umum terhadap seorang terpidana kasus korupsi. Namun demikian, istilah pemiskinan yang berarti sebuah hukuman untuk membuat seorang tersangka menjadi miskin akibat seluruh aset dan harta benda yang dimilikinya jelas sebagai sebuah tindakan yang tidak sejalan dengan konsep 'uqubah atau penjatuhan sanksi bagi seorang terdakwa menurut perspektif hukum pidana Islam. Sebab menurut hukum Pidana Islam hukuman harus proporsional sesuai dengan kejahatan yang dilakukannya, sehingga ada istilah qisas yaitu hukuman pembalasan secara seimbang. Dalam perspektif hukum Islam, seseorang diberi imbalan pahala sesuai dengan buah karya baiknya dan seseorang dihukum sesuai kejatan yang dilakukannya. Hal ini sesuai dengan firman Allah dalam Q.S. al-Baqarah/2: 286,

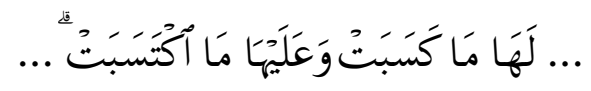
ia mendapat pahala (dari kebajikan) yang diusahakannya dan ia mendapat siksa (dari kejahatan) yang dikerjakannya..

Di samping itu pemiskinan terhadap koruptor tidak sejalan dengan sunnatullah mengenai konsep kaya miskin yang merupakan hukum Allah di alam raya ini, adanya orang kaya dan orang miskin agar terdapat hubungan timbal-balik yang sehat antara keduanya, pihak yang kaya tidak boleh terlalu kikir dengan harta yang dimiliknya, dan pihak yang miskin tidak boleh iri dengan harta milik orang lain, apalagi sampai mencuri atau merampok. Dalam hal ini Allah berfirman dalam QS. al-Nahll/16: 71 


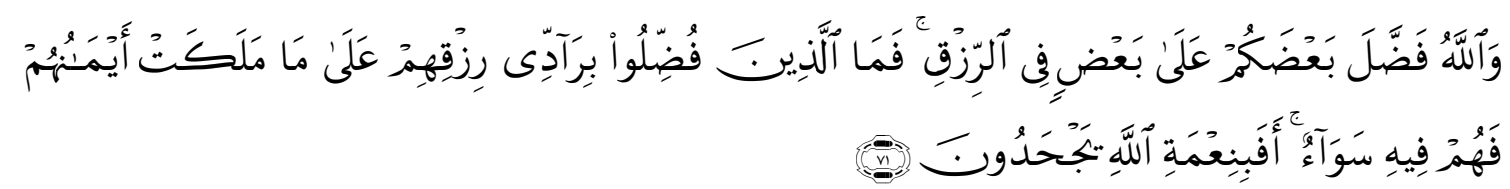

Dan Allah melebihkan sebahagian kamu dari sebagian yang lain dalam hal rezeki, tetapi orang-orang yang dilebihkan (rezekinya itu) tidak mau memberikan rezeki mereka kepada budak-budakyang mereka miliki, agar mereka sama (merasakan) rezeki itu, maka mengapa mereka mengingkari nikmat Allah

\section{Penutup}

Dalam kacamata hukum pidana positif, pemiskinan koruptor sebenarnya mendapat preseden dari putusan-putusan hakim yang menyita harta koruptor. Sementara dalam hukum pidana Islam, hukuman berupa pemiskinan terhadap pelaku koruptor dalam tindak pidana korupsi tidak bisa dibenarkan jika hukuman jenis ini dimaksudkan untuk membuat terpidana menjadi miskin, sebab kaya dan miskin adalah sunnatullah, dan hanya Allah yang menentukan apakah seseorang itu akan menjadi orang kaya, atau sebaliknya. Namun demikian, jika pemiskinan dipahami sebagai sebuah bentuk hukuman denda akibat korupsi yang dilakukannya, maka hal ini dapat dibenarkan dan pemiskinan dalam arti seperti ini merupakan sebauh bentuk hukuman takzir, yakni sebuah jenis hukuman dalam hukum pidana Islam yang ditetapkan oleh pemerintah, dan bukan secara tegas disebutkan dalam al-Qur'an dan hadis-hadis Nabi.

\section{Pustaka Acuan}

Adji, Indriyanto Seno. Korupsi dan Penegakan Hukum. Jakarta: Media, 2009.

Alatas, Syeid Hussein. Sosiologi Korupsi: Sebuah Penjelajahan dengan Data Kontemporer. Jakarta: LP3ES, 1983.

Alatas. Korupsi, Sifat, dan Fungsi. Jakarta: LP3ES, 1987.

Alfitra. "Modus Operandi Pidana Khusus Diluar KUHP: Korupsi, Money Laundring, dan Traffiking," dalam Penebar Swadaya, Jakarta, 2014.

Arief, Barda Nawawi. Bunga Rampai Kebijakan Hukum Pidana. Bandung: Citra Aditya, 1996.

Arief, Barda Nawawi. Kapita Selekta Hukum Pidana. Bandung: Citra Aditya, 2003.

Assiddiqie, Jimly. "Penegakan Hukum, Keadilan dan Hak Asasi Manusia," dalam Jurnal Keadilan, Vol. 2 Nomor 2 Tahun 2002.

Atmasasmita, Romli. "Pemberantasan Korupsi Tergantung Kepada Presiden," dalam Pikiran Rakyat, 11 Oktober 2004.

Atmasasmita, Romli. Korupsi, Good Governance dan Komisi Anti Korupsi Indonesia. (Jakarta: BPHN Dep.Keh \& Ham, 2002. 
Atmasasmita, Romli. Reformasi Hukum, Hak Asasi Manusia \& Penegakan Hukum. Bandung: Mandar Maju, 2001.

Azra, Azyumardi. "Agama dan Pemberantasan Korupsi," dalam Pramono U. Tanthowi. Membasmi Kanker Korupsi. Jakarta: t.p., 2004.

Bailey, David H. "Akibat Korupsi pada Bangsa-Bangsa yang Sedang Berkembang," dalam Mochtar Lubis (ed.). Bunga Rampai Korupsi. Jakarta: LP3ES, 1985.

Gunner, Bryan. Black Law Dictionary. Minnesota: Seven Edt West Group, StPaul, 1999.

I.G.M., Nurjana. Sistem Hukum Pidana dan Bahaya laten Korupsi. Yogyakarta: Pustaka Pelajar, t.t.

I.G.M., Nurjana. Wewenang Polri, dalam Penindakan KKN. Yogyakarta: t.p., 2003.

Legowo, TA. “Otonomi Daerah dan Akomodasi Politik Lokal," diakses Tanggal 20 Pebruari 2005.

M., Kusuma. Tegaknya Supermasi Hukum. Bandung: Remaja Rosdakarya, 2001.

Manan, Bagir. "Penegakan Hukum yang Berkeadilan," Kumpulan bahan Kuliah Pengembangan Sistem Hukum Indonesia Abad XXI, Program Pascasarjana Universitas Padjadjaran, Bandung, 2003,

Packer, Herbert. The Limits of Criminal Sanction. California: Stanford University Press, t.t. Pope, Jeremy. Strategi Memberantas Korupsi. Jakarta: TII dan Yayasan Obor Indonesia 2003. Purwadarminta. Kamus Umum Bahasa Indonesia. Jakarta: Depdikbud, 1996.

Santoso, Topo. Membumikan Hukum Pidana Islam: Penegakan Syariah dalam Wacana dan Agenda. Jakarta: Gema Insani, 2003.

Setiadi, Edi. Hukum Pidana Ekonomi. Bandung: Fakultas Hukum Unisba, 2004.

Soekanto, Soerjono. Sosiologi Hukum dalam Masyarakat. Jakarta: Rajawali Press, 1976.

Susanto, IS. "Kejahatan Korupsi di Indonesia: Produk Kebijakan Orde Baru," Pidato Pengukuhan Guru Besar Undip, Semarang, 1999.

Undang-undang RI N0 30 Tahun 2002 tentang Komisi Pemberantasan Korupsi.

Undang-undang RI N0 31 Tahun 1999 jo Undang-undang RI No 21 Tahun 2001 tentang Pemberantasan korupsi.

Widjojanto, Bambang. "Peran Masyarakat dalam Menghilangkan Budaya Korupsi di Indonesia," makalah disampaikan pada acara Halakah Tarjih Muhammadiyah Solo 2005.

Yusanto, Muhammad Ismail. "Islam dan Jalan Pemberantasan Korupsi," dalam http:// www.e-syariah.net. diakses tanggal 19 Maret 2005.

Yusuf, Muhammad. Merampas Asep Koruptor. Jakarta: Gramedia, 2013. 